\title{
Penerapan Metode Simple Multi-Attribute Rating Technique untuk Pemilihan Lokasi Kos Terbaik di Kawasan UIN Suska Riau
}

\author{
${ }^{1}$ Riszki Fadillah, ${ }^{2}$ Putri Anglenia, ${ }^{3}$ Astia Weni Syaputri, ${ }^{4}$ Mustakim \\ ${ }^{1,2,3,4}$ Program Studi Sistem Informasi, Fakultas Sains dan Teknologi UIN Sultan Syarif Kasim Riau \\ ${ }^{1,2,3,4}$ Puzzle Research Data Technology, Fakultas Sains dan Teknologi UIN Sultan Syarif Kasim Riau \\ J1. HR Soebrantas KM.18 No. 155 Panam Pekanbaru - Riau 28293 \\ Email: 1 fadillahriszki@ gmail.com, ${ }^{2}$ putrianglenia@ gmail.com, ${ }^{3}$ astia.wesya@ gmail.com, ${ }^{4}$ mustakim@uin- \\ suska.ac.id
}

\begin{abstract}
ABSTRAK
Information needs against boarding houses and the current location are important, to find the location of the boarding houses that fit the desires and confused to its decision because of the many boarding houses that are available. This research will be conducted on the application of the method of a decision support system to select the location of the area's finest boarding houses UIN Suska Riau using a few street names as alternative and criteria that have been tailored to their needs. To help someone chose the location of the boarding houses, then built the expected decision support systems can help a person to choose the location of the boarding houses. The methods used in decision support system is a method of Simple Multi-Attribute Rating Technique (SMART) to select or specify the location of the boarding houses the best there is in the region of UIN Suska Riau. From the results of the completion of a method using SMART obtained the rank of 20 alternatives with rank one in the street Mustamindo with a value of utilities 0.64 , in the alley of Iman value utilities is 0.63 , and so on until the 20th rank. After the implemented decision support system, further Testing is performed by using the user Acceptance Testing results obtained then the average response i.e. 97\%, in accordance with the reality of the expected response.
\end{abstract}

Kata kunci: Boarding House, Decision Support System, Simple Multi-Attribute Rating Technique, SMART.

\section{A. PENDAHULUAN}

Menurut Kamus Besar Bahasa Indonesia (KBBI), Kos atau dalam bahasa belanda "indekos" ialah tinggal dirumah orang lain dengan atau tanpa makan (dengan membayar setiap bulan) dengan harga dan fasilitas yang bervariasi [1]. Rumah kos atau Kos-Kosan merupakan suatu tempat tinggal yang digunakan cukup lama dan disewakan kepada orang lain dengan membayar setiap bulan atau setiap tahun dengan harga terjangkau dan fasilitas-fasilitas yang telah disediakan pada setiap kos [2].

Saat ini informasi tentang kos dan lokasi kos sangat penting, karena dengan adanya informasi kos-kosan akan mempermudah seseorang dalam memilih dan menentukan kos-kosan [1]. Namun untuk memilih suatu kos yang tepat dan baik tidak lah mudah, karena banyak faktor yang harus dipertimbangkan dalam pemilihan kos-kosan. Misalnya saja faktor harga, jarak tempuh, fasilitas, dan beberapa faktor lain [3] [4]. Di kota Pekanbaru sendiri kos-kosan merupakan suatu hal yang penting bagi para perantauan dari berbagai daerah yang ingin menuntut ilmu di Universitas Islam Negeri Sultan Syarif Kasim Riau (UIN Suska Riau) Pekanbaru dengan harga yang terjangkau dan dekat dengan kampus.

Sebenarnya mahasiswa yang menuntut ilmu di UIN Suska Riau memiliki pilihan untuk tinggal di asrama, kontrakan, kos atau bahkan membeli rumah sendiri. Jika mahasiswa ingin tinggal di asrama tentunya lebih dekat dengan kampus dan lebih murah, namun asrama memiliki kuotanya tersendiri jika penuh maka kita harus menunggu ada yang meninggalkan asrama. Jika memilih kontrakan maka harga yang di tawarkan relatif lebih mahal dan biasanya jika sendiri terlalu berat dalam hal biaya serta fasilitas yang belum ada. Sedangkan jika membeli rumah maka biaya yang akan dikeluarkan akan lebih besar dibandingkan dengan mengontrak rumah atau tinggal di asrama. Dengan demikian kos merupakan suatu alternatif pilihan bagi mahasiswa yang ingin tinggal dengan jarak yang relatif dekat dengan harga dan fasilitas yang dapat disesuaikan dengan kebutuhan dan budget, serta memiliki banyak pilihan. Dengan banyaknya pilihan koskosan yang berada disekitar kampus UIN Suska Riau, maka mahasiswa atau perantau harus cermat memilih kos-kosan terbaik sesuai dengan kriteria yang telah disesuaikan seperti faktor harga, jarak, fasilitas, kamar mandi, air, listrik, keamanan, parkiran, dan beberapa kriteria lain yang perlu dipertimbangkan sesuai dengan keputusan yang paling tepat [3].

Metode Simple Multi Attribut Rating Technique (SMART) adalah salah satu metode untuk pengambilan keputusan multi kriteria [5]. Setiap kriteria memiliki nilai bobot yang akan menentukan nilai kriteria mana yang paling penting dibandingkan dengan kriteria yang lainnya. Metode SMART memiliki kesederhanaan untuk merespon kebutuhan dan menganalisis respon dalam pembuatan keputusan sehingga metode SMART ini sering kali digunakan untuk melakukan pengambilan keputusan. Metode SMART dapat menjadi salah satu metode yang dapat membantu 
mahasiwa UIN Suska Riau dalam menentukan koskosan terbaik yang akan dipilih [6].

Pada penelitian sebelumnya yang dilakukan oleh Dwi Novianti pada tahun 2016 pada kasus Pemilihan Cafe Menggunakan SMART, hasil dari penelitian tersebut dapat menentukan cafe terbaik dengan mengukur kriteria yaitu fasilitas, biaya, lokasi, dan variasi menu yang menjadi tolak ukur pelanggan untuk memilih cafe terbaik [7]. Penelitian yang dilakukan oleh Chia-Yu Hsu, Julaimin Goh and Pei-Chann Chang pada tahun 2012 dengan judul Development of Decision Support System for House Evaluation and Purchasing, yaitu suatu pengembangan sistem pendukung keputusan untuk pembelian perumahan dengan pendekatan penyortiran. Sistem pendukung keputusan ini menyesuaikan dengan kebutuhan-kebutuhan konsumen baik itu fasilitas maupun lingkungan sekitar [8]. Selanjutnya yaitu penelitian yang dilakukan oleh Suryanto dan Muhammad Safrizal pada tahun 2015 untuk melakukan pemilihan karyawan terbaik dengan menentukan alternatif karyawan yang memenuhi syarat berdasarkan kriteria. Dengan melakukan penyebaran kuisioner kepada pengguna maka didapat nilai kisaran $83.57 \%$ dan $83 \%$ untuk manajer, sehingga sistem ini dapat memberikan rekomendasi yang tepat [5]. Penelitian yang dilakukan oleh Trinanda Syahputra, Milva Yetri, dan Siwi Dwi Armaya terkait dengan kualitas pemasukan pangan segar, dengan menganalissi permasalahan yang berkaitan dengan kualitas makanan yang berasal dari tumbuhan [9].

Berdasarkan ulasan dan permasalahan diatas maka penelitian ini mencoba menerapkan SMART untuk menentukan lokasi kos-kosan terbaik didaerah Pekanbaru khususnya untuk kawasan UIN Suska Riau, tujuan dari penelitian ini adalah untuk membantu para Mahasiswa dalam memberikan rekomendasi terhadap lokasi kos-kosan terbaik yang ada di kawasan kampus tersebut berdasarkan kriteria-keritera yang telah ditentukan yang diharapkan menjadi solusi terbaik dalam penyelesaian masalah. Penelitian ini juga membangun sebuah sistem berbasis web untuk memudahkan pencari kos-kosan yang dapat diakses baik mobile maupun web.

\section{B. METODOLOGI PENELITIAN}

Metodologi penelitian yang dilakukan untuk melakukan penelitian ini dapat dilihat pada gambar 1 :

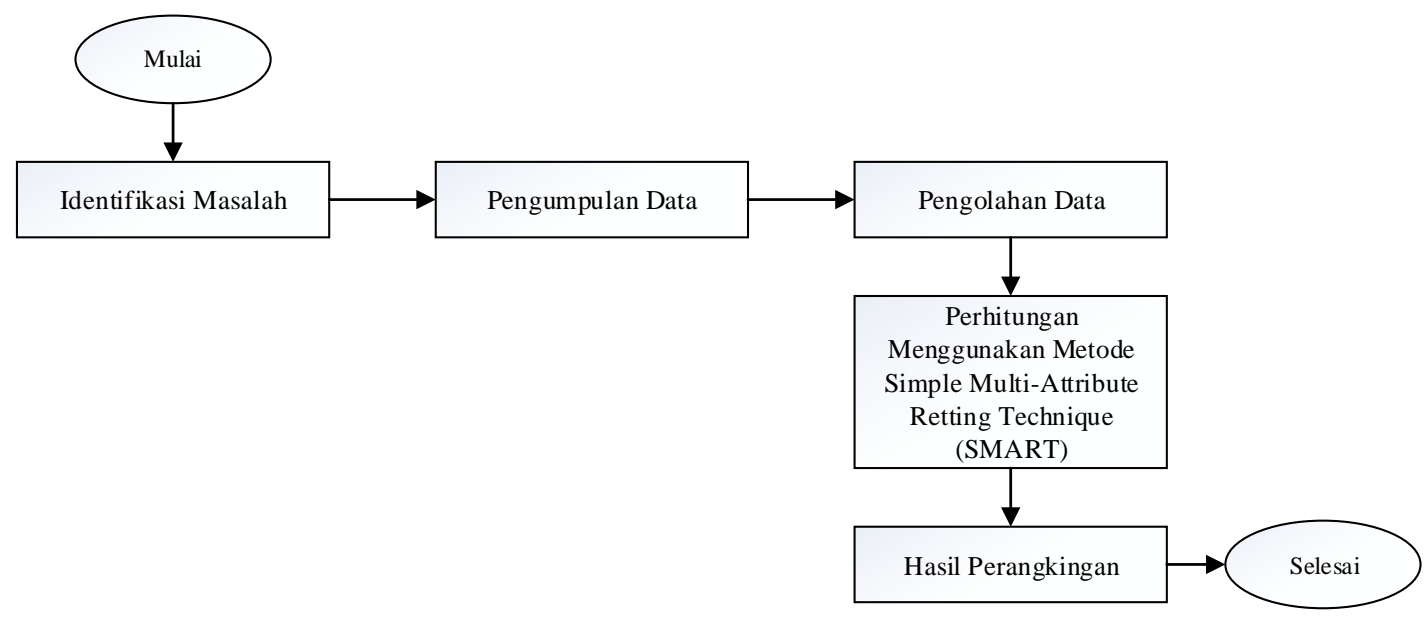

Gambar 1. Metodologi Penelitian

Metodologi penelitian yang dilakukan yaitu dengan melakukan identifikasi masalah pada kasus, kemudian melakukan pengumpulan data dengan wawancara, kemudian melakukan pengolahan data hasil wawancara dengan Microsoft Excel. Setelah selesai mengolah data kemudian melakukan langkah-langkah pada metode SMART dengan model rangking dari data-data yang telah diolah berdasarkan nilai utilities tertinggi. Selanjutnya mengimplementasikan kedalam sebuah sistem pendukung keputusan dengan bahasa pemrograman PHP.

\section{B.1. Simple Multi-Attribute Rating Technique (SMART)}

Simple Multi-Attribute Rating Technique (SMART) merupakan suatu metode yang dapat menangkap atau menerima dengan baik dari suatu kasus pengambilan keputusan untuk menjelaskan suatu hal atau kondisi yang bersifat kualitatif dan kuantitatif [10].Teknik pengambilan keputusan SMART merupakan pengambilan keputusan dari setiap alternatif yang terdiri dari beberapa kriteria, dimana setiap kriteria memiliki nilai dan bobotnya masing-masing.Kriteria yang paling penting dan memiliki pengaruh paling besar akan dibandingkan kriteria lainnya [11] [12] [14]. 
Pada metode SMART untuk penyelesaian kasus secara umum memiliki langkah-langkah sebagai berikut [12] [13]:

a. Identifikasi masalah yang terjadi

b. Menentukan kriteria-keriteria yang akan digunakan untuk menjadi tolak ukur penilaian.

c. Menentukan alternatif-alternatif yang ada

d. Pemberian bobot disetiap kriteria sesuai dengan alternatif, dengan persamaan

$$
W_{i j}=\frac{C_{o u t}-C_{\min }}{C_{\max }-C_{\min }}
$$

e. Melakukan proses normalisasi pada setiap kriteria di masing-masing alternatif, dengan persamaan

$$
\text { Normalisasi }=\frac{W_{i j}}{\sum_{i=1}^{n} W_{i j}}
$$

f. Menghitung nilai utilities di setiap alternatif untuk mendapatkan hasil akhir penilaian, dengan persamaan

$$
u\left(a_{i}\right)=\sum_{J=1}^{m} W_{j} u_{i}\left(a_{i}\right), \quad i=1,2, \ldots, m
$$

(3)

g. Melakukan perangkingan berdasarkan nilai utilities terbesar hingga nilai utilities terkecil.

\section{HASIL DAN ANALISIS}

Pada penelitian ini didapat sebuah masalah yaitu bagaimana menentukan lokasi kos-kosan terbaik untuk Mahasiswa di kawasan UIN Suska Riau sesuai dengan keadaan dan keinginan Mahasiswa. Penentuan kawasan kos ini berdasarkan kriteria-kriteria yang telah ditentukan untuk memberikan solusi dimana tempat yang baik sesuai dengan kriteria yaitu (C1) Harga, (C2) Jarak, (C3) Fasilitas Kamar, (C4) Luas Kamar, (C5) Kamar Mandi, (C6) Listrik, (C7) Fasilitas Umum, (C8) Lingkungan, (C9) Parkiran. Kriteria merupakan suatu unsur terpenting dalam melakukan penerapan untuk mengambil sebuah keputusan, kriteria menjadi ukuran dasar dalam setiap penilaian atau dalam penetapan sesuatu, dengan menggunakan kriteria ini lah akan didapat nilai-nilai dari setiap alternatif yang ada untuk mengukur tingkat kebutuhan dan kepentingan dari suatu alternatif. Alternatif yang digunakan pada penelitian ini dapat ditunjukan pada Tabel 1:

Tabel 1. Alternatif Pilihan

\begin{tabular}{llc}
\hline No & \multicolumn{1}{c}{ Alternatif } & Kode \\
\hline 1 & Jalan Asta Karya & A1 \\
2 & Ferum Trifana Town Regency & A2 \\
& Panam & \\
3 & Jalan Melayu 1 & A3 \\
4 & Vila Pesona & A4 \\
5 & J1 Bulucina & A5 \\
6 & J1 Satria & A6 \\
7 & Gg Al-Fazar & A7 \\
8 & J1 Jati Mandiri & A8 \\
9 & J1 Perumahan & A9 \\
10 & Gg Iman & A10 \\
11 & Gg Jalak (Merpati Sakti) & A11 \\
12 & J1 Bangau Sakti & A12 \\
13 & J1 Bina Krida Unri & A13 \\
14 & J1 Mustamindo & A14 \\
15 & J1 Garuda Sakti & A15 \\
16 & J1 Manunggal & A16 \\
17 & Jl. Garuda Sakti Gg. Melayu & A17 \\
18 & J1 Yuda Karya & A18 \\
19 & Garuda Sakti Km 1 Gg Muslimin & A19 \\
20 & Garuda Sakti Gg Amal & A20 \\
\hline
\end{tabular}

Alternatif merupakan suatu pilihan dalam komponen pengambilan keputusan, pada kasus ini yaitu pemilihan lokasi kos terbaik dikawasan UIN Suska Riau dipilih secara acak dengan asumsi yang terbaik dalam jangkauan Mahasiswa. Alternatif yang digunakan pada kasus ini yaitu nama-nama jalan yang terdapat di sekeliling kawasan UIN Suska Riau. Selain dari alternatif, terdapat 9 kriteria yang menjadi acuan utama dalam penentuan pemilihan lokasi kost. Pembobotan keriteria berdasarkan alternatif ditunjukan pada Tabel 2:

Tabel 2. Kriteria dan Pembobotan Kriteria

\begin{tabular}{cccccccccc}
\hline \multirow{2}{*}{ Alternatif } & \multicolumn{10}{c}{ Kriteria } \\
\cline { 2 - 9 } & C1 & C2 & C3 & C4 & C5 & C6 & C7 & C8 & C9 \\
\hline A1 & 0,50 & 0,33 & 0,00 & 0,50 & 1,00 & 1,00 & 0,00 & 1,00 & 1,00 \\
A2 & 0,50 & 0,67 & 0,33 & 0,00 & 1,00 & 0,00 & 0,57 & 1,00 & 1,00 \\
A3 & 0,50 & 0,67 & 0,33 & 1,00 & 1,00 & 1,00 & 0,43 & 1,00 & 1,00 \\
A4 & 0,00 & 0,67 & 1,00 & 0,50 & 1,00 & 1,00 & 0,14 & 1,00 & 1,00 \\
A5 & 0,50 & 1,00 & 0,33 & 0,50 & 1,00 & 0,00 & 0,00 & 1,00 & 0,00 \\
A6 & 0,00 & 0,67 & 0,33 & 1,00 & 1,00 & 0,00 & 0,29 & 1,00 & 1,00 \\
A7 & 0,00 & 0,33 & 0,67 & 0,50 & 1,00 & 1,00 & 0,14 & 1,00 & 1,00 \\
A8 & 0,50 & 0,00 & 0,00 & 0,00 & 1,00 & 1,00 & 0,00 & 1,00 & 1,00 \\
A9 & 0,50 & 0,67 & 0,00 & 0,50 & 1,00 & 0,00 & 0,14 & 0,00 & 1,00 \\
A10 & 0,50 & 0,33 & 1,00 & 1,00 & 1,00 & 0,00 & 1,00 & 1,00 & 1,00 \\
A11 & 0,00 & 0,00 & 0,67 & 0,50 & 1,00 & 1,00 & 0,71 & 1,00 & 1,00
\end{tabular}




\begin{tabular}{cccccccccc}
\hline \multirow{2}{*}{ Alternatif } & \multicolumn{10}{c}{ Kriteria } \\
\cline { 2 - 10 } & C1 & C2 & C3 & C4 & C5 & C6 & C7 & C8 & C9 \\
\hline A12 & 0,50 & 0,00 & 0,33 & 0,50 & 1,00 & 0,00 & 0,14 & 1,00 & 1,00 \\
A13 & 0,00 & 1,00 & 0,33 & 1,00 & 1,00 & 1,00 & 0,43 & 1,00 & 1,00 \\
A14 & 1,00 & 1,00 & 1,00 & 0,50 & 1,00 & 1,00 & 0,14 & 1,00 & 1,00 \\
A15 & 0,50 & 1,00 & 0,67 & 1,00 & 1,00 & 1,00 & 0,29 & 1,00 & 1,00 \\
A16 & 0,50 & 0,67 & 0,67 & 0,50 & 0,00 & 1,00 & 0,43 & 1,00 & 1,00 \\
A17 & 0,50 & 1,00 & 0,33 & 0,50 & 1,00 & 1,00 & 0,29 & 1,00 & 1,00 \\
A18 & 0,50 & 1,00 & 0,67 & 0,50 & 1,00 & 0,00 & 0,00 & 0,00 & 0,00 \\
A19 & 0,50 & 0,33 & 0,33 & 0,50 & 1,00 & 0,00 & 0,29 & 1,00 & 1,00 \\
A20 & 0,50 & 0,00 & 1,00 & 0,50 & 1,00 & 0,00 & 0,00 & 1,00 & 1,00 \\
\hline
\end{tabular}

Penilaian bobot kriteria disesuaikan dengan rentang yang telah ditentukan sebelumnya di setiap kriteria kemudian dilakukan perhitungan dengan menggunakan persamaan (1), tabel 2 diatas merupakan hasil dari pembobotan kriteria yang telah dilakukan pengolahan. Untuk menentukan bobot kriteria dengan menggunakan persamaan (1) dengan mengurangkan nilai bobot dengan nilai minimun pada kriteria. Tahapan selanjutnya adalah melakukan proses normalisasi data, yang ditunjukan pada tabel 3:

Tabel 3. Normalisasi Data

\begin{tabular}{cccccccccc}
\hline \multirow{2}{*}{ Alternatif } & \multicolumn{10}{c}{ Kriteria } \\
\cline { 2 - 9 } & $\mathbf{C 1}$ & $\mathbf{C 2}$ & $\mathbf{C 3}$ & $\mathbf{C 4}$ & $\mathbf{C 5}$ & $\mathbf{C 6}$ & $\mathbf{C 7}$ & $\mathbf{C 8}$ & $\mathbf{C 9}$ \\
\hline A1 & 0,50 & 0,33 & 0,00 & 0,50 & 1,00 & 1,00 & 0,00 & 1,00 & 1,00 \\
A2 & 0,50 & 0,67 & 0,33 & 0,00 & 1,00 & 0,00 & 0,57 & 1,00 & 1,00 \\
A3 & 0,50 & 0,67 & 0,33 & 1,00 & 1,00 & 1,00 & 0,43 & 1,00 & 1,00 \\
A4 & 0,00 & 0,67 & 1,00 & 0,50 & 1,00 & 1,00 & 0,14 & 1,00 & 1,00 \\
A5 & 0,50 & 1,00 & 0,33 & 0,50 & 1,00 & 0,00 & 0,00 & 1,00 & 0,00 \\
A6 & 0,00 & 0,67 & 0,33 & 1,00 & 1,00 & 0,00 & 0,29 & 1,00 & 1,00 \\
A7 & 0,00 & 0,33 & 0,67 & 0,50 & 1,00 & 1,00 & 0,14 & 1,00 & 1,00 \\
A8 & 0,50 & 0,00 & 0,00 & 0,00 & 1,00 & 1,00 & 0,00 & 1,00 & 1,00 \\
A9 & 0,50 & 0,67 & 0,00 & 0,50 & 1,00 & 0,00 & 0,14 & 0,00 & 1,00 \\
A10 & 0,50 & 0,33 & 1,00 & 1,00 & 1,00 & 0,00 & 1,00 & 1,00 & 1,00 \\
A11 & 0,00 & 0,00 & 0,67 & 0,50 & 1,00 & 1,00 & 0,71 & 1,00 & 1,00 \\
A12 & 0,50 & 0,00 & 0,33 & 0,50 & 1,00 & 0,00 & 0,14 & 1,00 & 1,00 \\
A13 & 0,00 & 1,00 & 0,33 & 1,00 & 1,00 & 1,00 & 0,43 & 1,00 & 1,00 \\
A14 & 1,00 & 1,00 & 1,00 & 0,50 & 1,00 & 1,00 & 0,14 & 1,00 & 1,00 \\
A15 & 0,50 & 1,00 & 0,67 & 1,00 & 1,00 & 1,00 & 0,29 & 1,00 & 1,00 \\
A16 & 0,50 & 0,67 & 0,67 & 0,50 & 0,00 & 1,00 & 0,43 & 1,00 & 1,00 \\
A17 & 0,50 & 1,00 & 0,33 & 0,50 & 1,00 & 1,00 & 0,29 & 1,00 & 1,00 \\
A18 & 0,50 & 1,00 & 0,67 & 0,50 & 1,00 & 0,00 & 0,00 & 0,00 & 0,00 \\
A19 & 0,50 & 0,33 & 0,33 & 0,50 & 1,00 & 0,00 & 0,29 & 1,00 & 1,00 \\
A20 & 0,50 & 0,00 & 1,00 & 0,50 & 1,00 & 0,00 & 0,00 & 1,00 & 1,00 \\
\hline
\end{tabular}

Normalisasi merupakan perbandingan setiap nilai bobot pada kriteria dengan jumlah bobot pada kriteria tersebut dengan menggunakan persamaan (2). Nilai nomalisasi yang didapat nantinya akan digunakan untuk menentukan nilai utilities. Nilai normalisasi sendiri didapatkan dari nilai bobot kriteria pada setiap alternatif kemudian dibagi dengan jumlah bobot kriteria di setiap kriteria sesuai dengan persamaan (2). Nilai utility dari proses pembobotan dapat dilihat pada gambar 2 : 


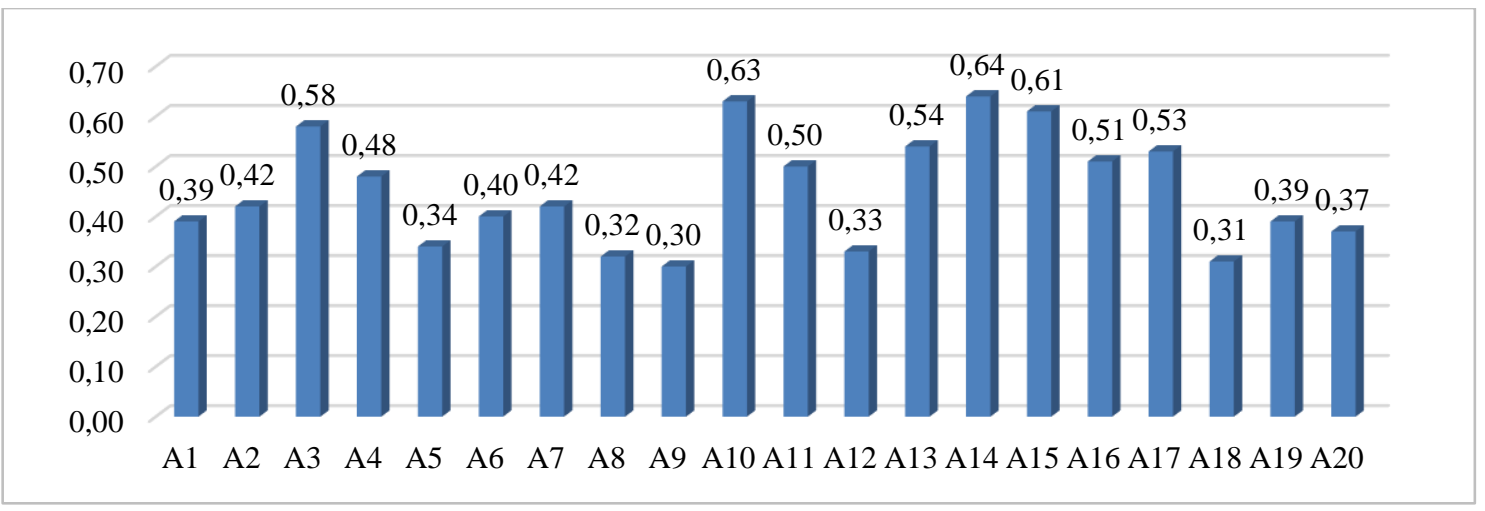

\section{Gambar 2. Diagram Nilai Utilities}

Nilai utilities merupakan nilai akhir dari penjumlahan seluruh kriteria pada alternatif. Nilai utilities digunakan untuk melakukan perangkingan pada tahap akhir metode SMART. Nilai utilities sendiri merupakan hasil operasi penjumlahan dari nilai yang telah dinormalisasi pada setiap alternatif, sesuai dengan persamaan (3). Berdasarkan hasil perangkingan metode SMART maka dapat diperoleh alternatif terbaik dari serangkaian proses metode, yang dapat ditunjukan pada gambar 3:

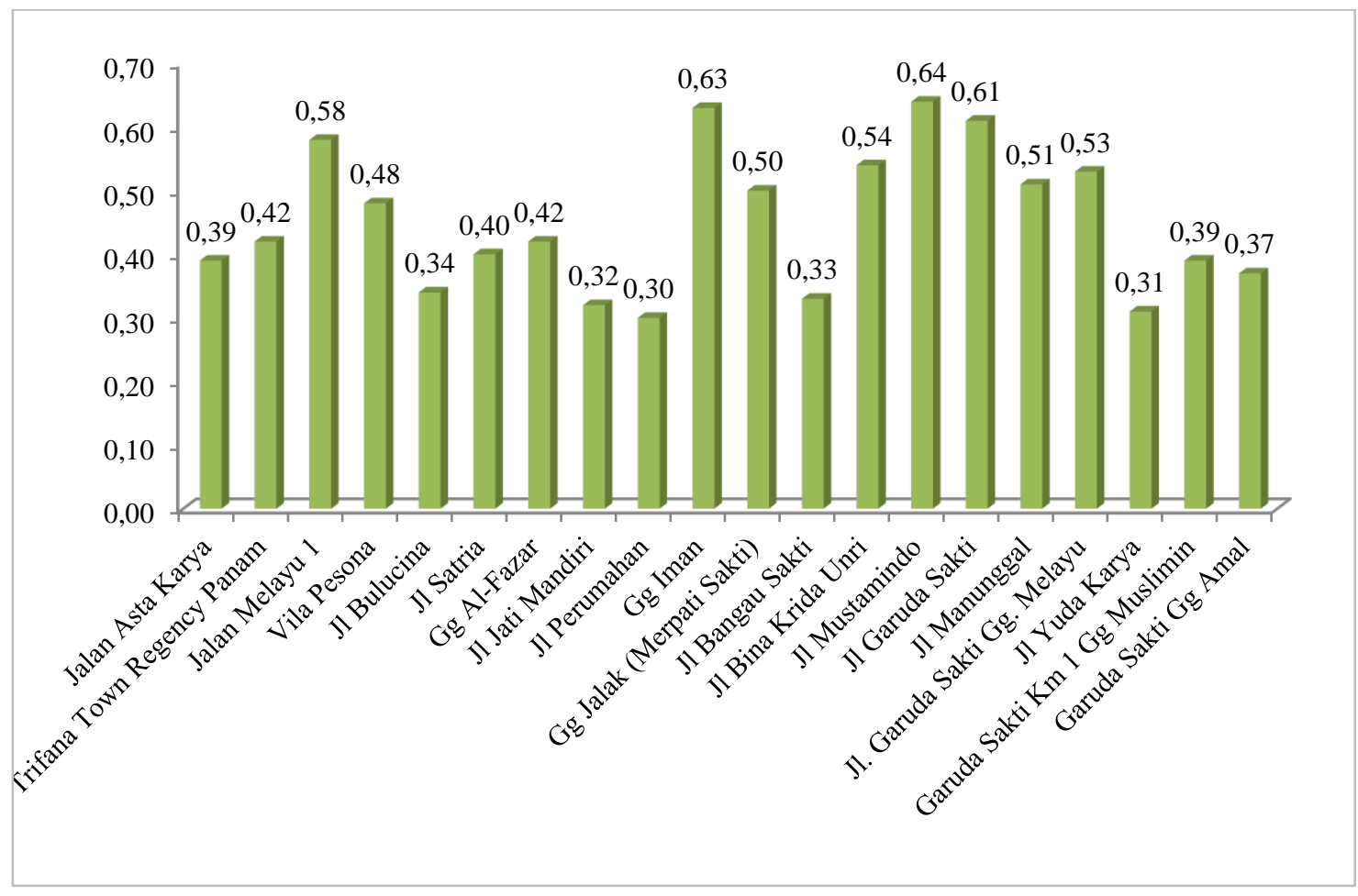

\section{Gambar 3. Diagram Perangkingan}

Semakin besar nilai utilities yang dihasilkan pada suatu alternatif maka akan semakin bagus nilai yang didapat pada alternatif tersebut. Pada diagram diatas dapat dilihat bahwa nilai utilities tertinggi adalah Jalan Mustamindo dengan nilai 0,64. Maka, untuk menentukan lokasi kos-kosan terbaik dengan menggunakan metode SMART yaitu Jalan Mustamindo, Gang Iman, Jalan Garuda Sakti adalah alternatif terbaik dengan nilai utilities tertinggi, dan seterusnya sesuai dengan nilai utilities yang dimiliki setiap alternatif. Hasil proses rekomendasi SMART diimplementasikan kedalam bahasa pemrograman untuk dapat memudahkan pengguna dalam memilih lokasi kos sesuai dengan kriteria yang diharapkan. Design interface utama dari sistem tersebut dapat dilihat pada gambar 4: 


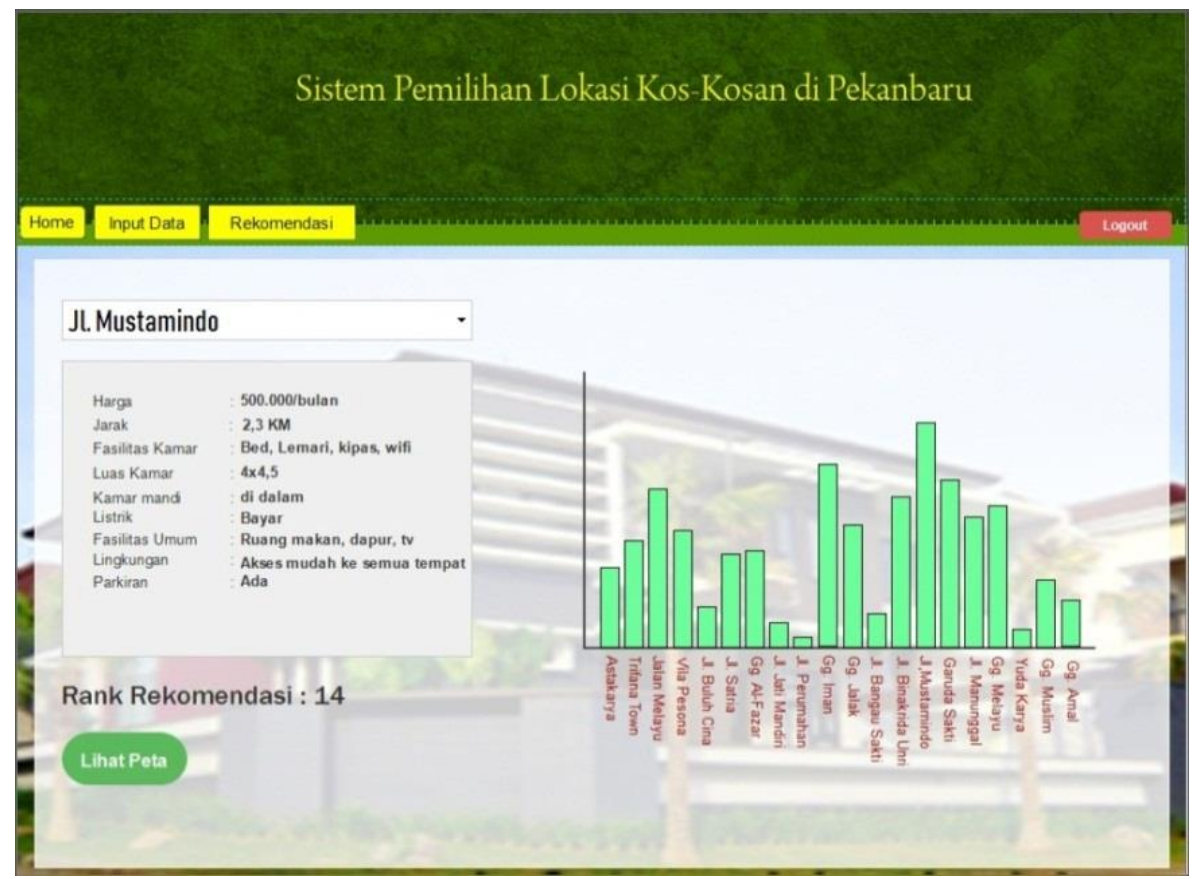

Gambar 4. Menu Hasil Perhitungan SMART

Menu hasil perhitungan SMART ini merupakan hasil akhir pada proses sistem pemilihan lokasi kos-kosan terbaik, dalam sistem tersebut dapat terlihat diagram batang pada setiap alternatif, nama jalan yang menjadi alternatif serta detail koskosan berdasarkan kriteria yaitu harga, jarak, fasilitas kamar, luas kamar, kamar mandi, listrik, fasilitas umum, lingkungan, parkiran. Selanjutnya sistem tersebut dapat menampilkan lokasi jalan atau alternatif melalui peta. Setelah melakukan tahap implementasi selanjutnya yaitu tahap pengujian dengan menggunakan pengujian User Acceptance Testing (UAT) yang digunakan untuk validasi keberhasilan sistem terhadap pengguna. Hasi uji UAT dapat ditunjukan pada tabel 4:

Tabel 4. Hasil Uji UAT

\begin{tabular}{|c|c|c|}
\hline NO & Responden & Persentase \\
\hline 1. & Responden 1 & $96 \%$ \\
\hline 2. & Responden 2 & $98 \%$ \\
\hline 3. & Responden 3 & $99 \%$ \\
\hline 4. & Responden 4 & $96 \%$ \\
\hline 5. & Responden 5 & $98 \%$ \\
\hline 6. & Responden 6 & $97 \%$ \\
\hline 7. & Responden 7 & $97 \%$ \\
\hline 8. & Responden 8 & $96 \%$ \\
\hline 9. & Responden 9 & $97 \%$ \\
\hline \multirow[t]{2}{*}{10} & Responden 10 & $98 \%$ \\
\hline & Rata-Rata & $97 \%$ \\
\hline
\end{tabular}

Sesuai dengan respon pada tabel diatas, didapatkan hasil persentase sistem dengan rata-rata pada angka 97\%, sesuai dengan realitas jawaban yang diharapkan, sehingga sistem ini telah dikatakan layak untuk digunakan, dan dapat membantu dalam menentukan lokasi kos-kosan terbaik.

\section{KESIMPULAN}

Berdasarkan hasil penelitian dan pembahasan yang telah dilakukan pada penerapan metode Simple Multi-Attribute Rating Technique (SMART) untuk melakukan penelitian terhadap pemilihan lokasi kos-kosan terbaik pada kawasan kampus UIN Suska Riau didapatkan perangkingan nilai kriteria berdasarkan alternatif maka didapatkan Jalan Mustamindo merupakan lokasi terbaik untuk pemilihan lokasi kos-kosan terbaik di kawasan UIN Suska Riau dengan nilai 0,64 , kemudian 0,63 pada Gang Iman, 0,61 pada Jalan Garuda Sakti, dan seterusnya hingga yang terakhir yaitu Jalan Perumahan dengan nilai 0,30. Jadi, pada kawasan UIN Suska Riau lokasi untuk kos-kosan terbaik berdasarkan kriteria-kriteria yang diusulkan maka Jalan Mustamindo merupakan alternatif terbaik sebagai lokasi kos di kawasan tersebut. Hasil pengujian berdasarkan User Acceptance Testing (UAT) maka diperoleh hasil respon rata-rata yaitu $97 \%$, sesuai dengan realitas jawaban yang diharapkan.

\section{REFERENSI}

E. S. T. A. Putra Aditya Primanda, "Pemilihan Kost di Sekitar Universitas Brawijaya menggunakan Metode Analitycal Hierarchy Process (AHP) dan Simple Additive Weighting (SAW)," Jurnal Pengembangan Teknologi Informasi dan Ilmu Komputer, vol. 2, no. 6, pp. 20942103, 2018.

[2] N. A. T. Y. A. Budi Harijanto, "Pengembangan Aplkasi Pemilihan Kost di 
Kota Malang dengan Metode AHP dan Promethee," Jurnal Informatika Polinema , vol. 4, no. 3, pp. 229-234, 2018.

[3] Y. H. A. Herik Sugianto, "Sistem Pendukung Keputusan Pemilihan Tempat Kost Khusus Mahasiswa dengan Metode AHP dan TOPSIS Berbasis Web (Studi Kasus: Kota Pontianak)," Jurnal Sistem dan Teknologi Informasi (JUSTIN), vol. 1, no. 1, pp. 1-6, 2016.

[4] J. N. M. P. Elisabet Simbolon, "Sistem Pendukung Keputusan Pemilihan Tempat Kos Menerapkan Metode Weighted Aggregated Sum Product Assessment (WASPAS)," Seminar Nasional Sains \& Teknologi Informasi (SENSASI), pp. 484487, 2018.

[5] M. S. Suryanto, "Sistem Pendukung Keputusan Pemilihan Karyawan Teladan dengan Metode SMART (Simple Multi Attribute Rating Technique)," Jurnal CoreIT, vol. 1, no. 2, pp. 25-29, 2015.

[6] K. D. K. W. M. R. A. S. Tisa Magrisa, "Implementasi Metode Smart Pada Sistem Pendukung Keputusan Pemilihan Kegiatan Ekstrakurikuler Untuk Siswa Sma," Informatika Mulawarman : Jurnal Ilmiah Ilmu Komputer , vol. 13, no. 1, pp. 49-55, 2018.

[7] I. F. A. D. M. K. Dwi Novianti, "Sistem Pendukung Keputusan Berbasis Web Untuk Pemilihan Cafe Menggunakan Metode Smart (Simple Multi-Attribute Rating Technique) (Studi Kasus : Kota Samarinda)," Prosiding Seminar Sains dan Teknologi FMIPA Unmul, pp. 461-465, 2016.

[8] J. G. a. P.-C. C. Chia-Yu Hsu, "Development of Decision Support System House Evaluation and Purchasing," International Journal of Computer and Information Engineering, vol. 6, no. 5, pp. 574-579, 2012.

[9] M. Y. S. D. A. Trinanda Syahputra, "Sistem Pengambilan Keputusan dalam Menentukan Kualitas Pemasukkan Pangan Segar Metode SMART," JURTEKSI (Jurnal Teknologi dan Sistem Informasi), vol. IV, no. 1, pp. 7-12, 2017.

[10] R. R. Risawandi, "Study of the Simple Multi-Attribute Rating Technique For Decision Support," International Journal of Scientific Research in Science and Technology, vol. 2, no. 6, pp. 491-494, 2016.

[11] D. A. A. U. D. I. R. R. Dodi Siregar, "Research of Simple Multi-Attribute Rating Technique for Decision Support," Journal of Physics: Conference Series , pp. $1-6,2017$.
[12] A. S. Honggowibowo, "Sistem Pendukung Keputusan Penerimaan Calon Mahasiswa Baru Jalur Prestasi di Sekolah Tinggi Teknologi Adisutjipto Menggunakan Simple Multi Attributerating Technique," JURNAL ANGKASA, vol. VII, no. 2, pp. 31-38, 2015.

[13] Richa Dwi Kusmiyanti, Mustakim Mustakim. Analisis Sensitifitas Model Smart-AHP dengan Smarter ROC Sebagai Pengambilan Keputusan Multi Kriteria. Seminar Nasional Teknologi Informasi Komunikasi dan Industri (SNTIKI) 9. 209218. 2018.

[14] Richa Dwi Kusmiyanti, Mustakim Mustakim. Analisis Sensitifitas Metode Simple Multi Attribute Rating Technique Terhadap Pembobotan Analytic Hierarchy Process. Seminar Nasional Teknologi Informasi Komunikasi dan Industri (SNTIKI) 8. 2017. 